\title{
Choice of Beef Herd Adaptation Strategy on Canadian Prairie Mixed Farms Under Extreme Climate Events
}

\author{
Santosh Poudela, Surendra N. Kulshreshtha ${ }^{a}$
}

\begin{abstract}
Economic impact of climate extremes on beef operation is expected to be significant due to its direct impact on feed production. Impact of such events on farm management and longer term farm financial situation is relatively unstudied in the Canadian Prairie. This study compared three alternative beef herd management strategies in dealing with climate extreme events under reference climate scenario of 1971-2000 and the future scenario of 2041-2070. The study used farm simulation model that integrated the model of cattle herd simulation, pasture model, crop simulation model combined with models of economic decisions. Purchasing feed and maintaining herd size is preferred option in dealing with drought. Changes in management such as early weaning combined with limit feeding strategies reduce the feed demand and also reduce the financial burden during the years of extreme event, but it has severe negative consequences on amount of slaughter cattle sold. Cull herd strategy not only reduces feed demand but also increases income from sell of herd during the year/s of extreme event, but it severely impacts the farm's long term output supply potential. However, expansion of existing agriculture risk management policy to cover climate risk in beef production is necessary to support farmers in the year/s to extreme events.
\end{abstract}

Keywords

Climate extreme, adaptation strategies, economic impact

Canada's beef industry is the largest single commodity source of farm cash income with an average $15.4 \%$ contribution during 2001-2010 period. Beef cattle production in Alberta and Saskatchewan provinces dominates the Canadian beef industry. Almost half of the Canadian farm cash receipt from cattle and calves was produced from the province of Alberta and the second highest of $16 \%$ was from Saskatchewan in 2011 (Kulshreshtha 2012). Number of farms reporting beef cattle in Saskatchewan and Alberta is continuously decreasing in recent years, but, total beef inventory remains constant or slightly increasing. That indicates the increasing size of beef farm in Alberta and Saskatchewan in recent years [AAFC (Alberta Agriculture and Forestry) 2014]. Despite growing importance of beef production, the prairies' beef cattle production is a relatively unstudied area from the economics and risk management point of view.

aUniversity of Saskatchewan, Saskatoon, Canada

\section{Correspondent Author:}

Surendra N. Kulshreshtha, Deaprtment of Agricultural and Resource Economics, Univerity of Saskatchewan, Saskatoon, SK, S7N 5A8, Canada 
The Canadian Prairies have witnessed severe events of climate extremes in the past. Such events have caused severe impact on prairie agriculture including livestock production. Examples of some severe multi-year droughts are: 1890s, 1910s, 1930s, late 1950s to early 1960s, 1980s, 1999-2005, and 2009-2010. Livestock production was adversely affected through feed shortages during those events. An example is the prairie droughts of 1987-1988 when livestock production was adversely affected through the effects on feed, from dust storms, and the lack of suitable pasture land [IISD (International Institute for Sustainable Development) 1997]. Droughts of 2001 and 2002 caused severe impact on livestock production due to the widespread scarcity of feed and water. Livestock inventories sharply decreased (AAFC 2013).

Climate change in the future is believed to increase the variability of climate variables with more frequent extreme events (Zhang et al. 2000; Khandekar 2004; Barrow 2009; Price et al. 2011; Bonsal et al. 2013; Paimazumder et al. 2013). Such events are expected to impact grass land and forage productivity and quality in the future. Rowlinson (2008) and Thornton et al. (2008) said that livestock is impacted in two ways: direct physiological effect, and indirect effect through the impact on grassland and rangeland productivity. Heat stress reduces the rate of animal feed intake and results in poor growth performance, and inadequate water and increased frequency of drought lead to loss of resources including grassland and rangeland. Belasco, Cheng, and Schroeder (2015) said that long term exposure of cattle to extreme weather has negative impacts on average daily gain, and also increases the rate of mortality. Seo and Mendelsohn (2007) showed that both the number of livestock and revenue per farm increased significantly with the increasing temperature under all the climate scenarios considered, except for dairy cattle. The similar result was found for the scenarios with the decrease in precipitation, implying that livestock producers could make positive profit under the future hotter and drier condition by the proper management of livestock. Therefore, impact of climate change can be severe on beef production in the future unless farmers' practices are appropriate strategies in managing adverse effect on livestock production during extreme climate events. Appropriate choice of coping strategies therefore is an important decision to maintain the good financial health of the farm. This study aimed at assessing the efficacy of selected coping strategies in dealing with climate extreme events impacting feed shortages during the baseline scenario of 1971-2000 and future scenario of 2041-2070 in two beef cattle farms-one in Swift Current, Saskatchewan, and another in Pincher Creek, Alberta. The study assessed three adaptation strategies: (1) purchasing feed; (2) changes in herd management; (3) cull herd in dealing with feed shortages during extreme climate events.

\section{REVIEW OF BEEF CATTLE ADAPTATIONS DURING CLIMATE CHANGE AND EXTREMES}

Bastian et al. (2006) had observed the following as beef herd coping strategies in extreme years: purchasing additional feed for livestock, livestock herd liquidation, participating in government assistance program, and undertaking other management alternatives like early weaning of calves, selling of retained yearlings, and addition of alternative crop and livestock enterprises. Ritten et al. (2011) recommended different drought management strategies for cattle producers which can be broadly grouped into two classes: purchasing additional feed, and reducing feed demand of the herd. The first strategy is the most common one and it involves purchasing feed to substitute for reduced forage production. Choice of feed to buy depends on its availability, season of feeding, type of animal, and the 
price of feed alternatives. The second strategy helps reduce nutritional demand of the herd. This can be done by partial liquidation of the herd which provides some immediate revenues, and reduces pressure on forage and pasture. However, this adds cost to rebuild the herd after drought or reduces revenues afterwards. Another option in reducing herd nutritional demand is by early weaning of calve; a benefit of this would be that there is no additional cost in securing feed. This, however, can result in either fewer or lighter weight animals to sell in the future.

Some producers may want to keep the herd and purchase feed instead of selling herd right away and purchase them later. In evaluating the effect of drought in cattle farm in Australia, Foran and Smith (1991) tested three different coping strategies. The strategy of average firm is to ignore the drought in the hope that the rain will come soon. The high stock herd farm sells the cattle right after the first indication of the drought. In contrast, the low-stock farm maintains herd size even in drought by introducing different management strategies. Nagler et al. (2007) reported the common drought coping strategies in US, which included purchasing additional feed, reduction in herd size, early weaning of calves, and selling of retained yearlings, and addition of alternative crop enterprises. OMAFRA (Ontario Ministry of Agriculture Food and Rural Affairs) (2012) advised three options for dealing with feed shortages: (1) moving livestock to where abundant feed and forages available; (2) buying feed; and (3) culling herd.

Smith and Foran (1992) and Gillard and Moneypenny (1990) investigated the economic effect of alternative destocking rates as a management strategy in extreme events in Australia. They found that strategy of substantial destocking is better for longer term drought management than the policy of hopeful inaction. According to Ritten et al. (2011), maintaining same herd size by purchasing feed adds extra cost to the farm and is beneficial only if the cattle price is expected to increase or at least remain the same; otherwise herd liquidation may be a good strategy during the period of feed shortages. However, Rasby (2013) advised some adjustments in timing and management of farm operation to cope with the effect of drought events before herd liquidations. He suggested early weaning of calves, early pregnancy test, and early sell of open cows as drought management strategies. Similarly, DEPI (Department of Environment and Primary Industries) (2014) recommended that limit feeding and controlled weight loss of cattle can lower the pressure on feed and can be a good coping strategy for drought-induced feed shortage period. SMA (Saskatchewan Ministry of Agriculture) (2008), AARD (Alberta Agriculture and Rural Development) (2011), and interview of farmers from the study sites made available by Bruno (2013) suggested that feed management, changes in timing of herd operations, and reduction in herd size are among the most common strategies in dealing with drought events.

\section{STUDY METHODOLOGY}

The study used whole farm simulation model that integrated the model of cattle herd simulation, pasture model, crop simulation model combined with models of economic decisions. Two mixed farms-one in Swift Current, Saskatchewan and another in Pincher Creek, Alberta - were developed using farm construct approach. The whole farm simulation was simulated over 30 years from 1971 to 2000 for baseline scenario and 2041 to 2070 for future scenario. A cattle herd simulation was done to simulate the Canadian Prairie beef cattle operations; its input required and output produced. Crop yield estimate was done by using FAO (Food and Agriculture Organization)'s AquaCrop simulation model and pasture productivity estimate was done by using Saskatchewan Research Council's forage yield calculator. The impacts of climate change and extreme events on beef cattle production were linked through the impacts on crops 
and forages, and linking them to feed availability for beef cattle. Direct impact on livestock productivity performance could not be considered due to inadequate information related to impact of climate change and extremes on beef cattle performance and productivity.

The crops and silage, hay and pasture area were fixed throughout the 30 years simulation period. Crop area available was first used to produce feed grain and silage demand of the herd and remaining area was used to produce grain for market. Hay and pasture areas were set to match their demand and supply in an average climate year. Land from one use could not be transferred to another use. Pasture was an established native mixed pasture. The farm would keep $40 \%$ of yearly total hay and grain in inventory for any unforeseen reason, every year. It is assumed that beef cattle herd size is determined by the carrying capacity of pastureland to meet the summer grazing need. During the years of extreme events, reduced pasture supply would have impact on cattle feeding. It is assumed that farmers choose one of the three following alternative strategies to meet summer pasture: (1) purchasing feed; (2) changes in herd management; (3) culling herd. Least cost linear programming approach was used to decide which feed grains to produce to feed the beef herd. Crop mix for the market was determined by formulating a multi-year linear programming problem by maximizing present value of yearly gross margin flow. The major revenue items were sale of beef cattle, crops, and surplus hay. Results of beef cattle herd simulation, crop and forage simulation, as well as least cost feed and multi-year crop mix linear programming (LP) models were linked to perform whole farm simulation.

\section{Farm Characteristics}

Statistics Canada (2012) information on mixed beef-crop farm specific to study sites was used in building study farms for these locations. The study farm of Pincher Creek had 1,700 acre native and tame mixed pasture, 686 acre crop area including hay and 307 beef herds (100 cows, 88 calves, 16 replacement heifers, 6 bulls, and 97 finishers). The study farm of Swift Current had 1,500 acre native and tame mixed pasture, 1,057 acre crop area including hay and 198 beef herds (86 cows, 74 calves, 13 replacement heifers, 4 bulls, and 21 finishers). Crop portfolio of the farm included four major crops grown in the study sites: canola, wheat, feed barley, and maize. The study farm of Pincher Creek was comparatively beef oriented with more beef head. Swift Current farm was more crop oriented with larger crop acre and fewer beef head. With regard to climate, Pincher Creek receives more average precipitation and Swift Current has comparatively hotter and drier climate. A major soil type of the Swift Current is classified as brown soil and the eco-region of the area is prairie ecozone dominated by mixed prairie grassland. The major vegetation types of mixed grass land in Swift Current sites are wheatgrass and needle grass. The sustainable stocking rate, supply of forages, which is measured in terms of Animal Unit Month (AUM/acre) of mixed grassland, is .38 (Thorpe 2007). Main soil type of Pincher Creek is black thin soil with foothill rough fescue as dominant vegetation type with mix of Columbian needle grass and wheatgrass. The sustainable stocking rate for Pincher Creek is .58 AUM/acre (Adams et al. 2003).

\section{Pasture and Crop Yield Estimates}

Long term average pasture yield estimation for the baseline and the future scenario provided by Thorpe (2011) was used to generate yearly value for the 30-year simulation period in both the scenarios using forage yield calculator developed by Saskatchewan Research Council (J. Thorpe, personal communication, 2014). The calculator provides the forage production for a given forage-year-precipitation. Average pasture productivity for 30-year period in the future is estimated to decrease by about $5 \%$ in Pincher Creek 


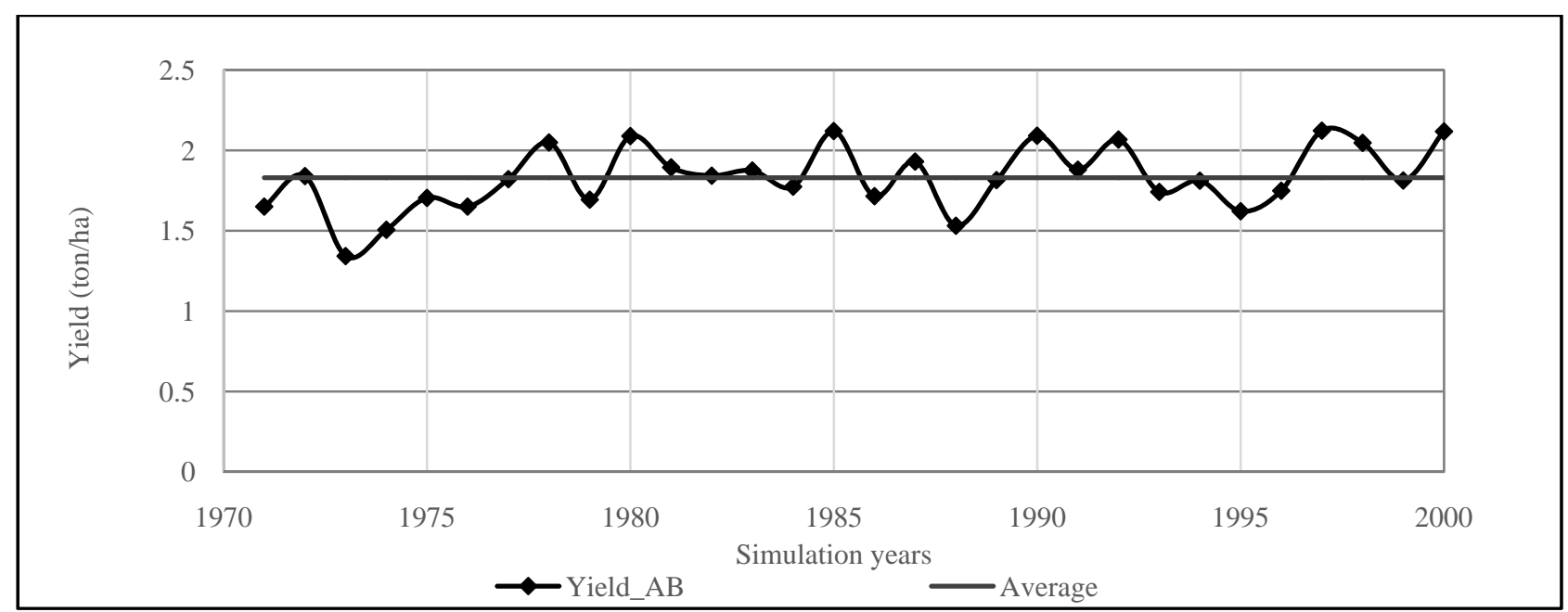

Figure 1. Pasture Yield Forecast Under Baseline Scenario in Pincher Creek Study Site.

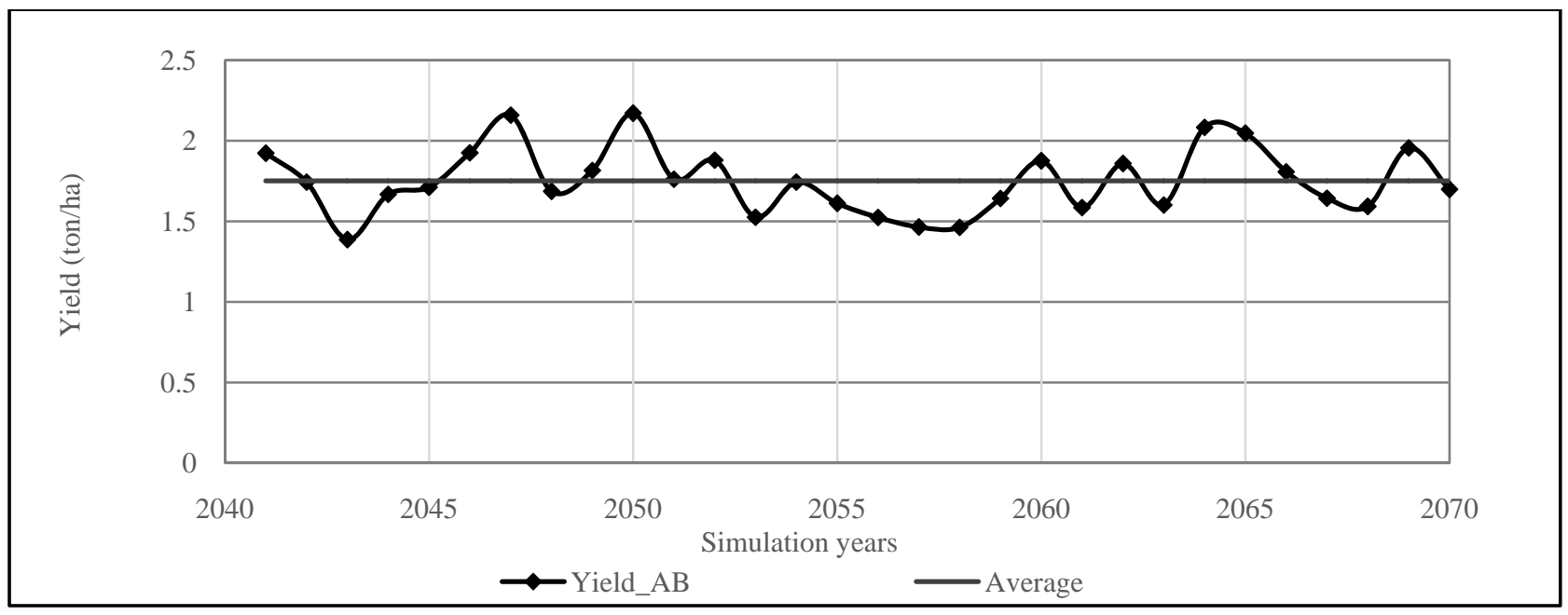

Figure 2. Pasture Yield Forecast Under Baseline Scenario in Pincher Creek Study Site.

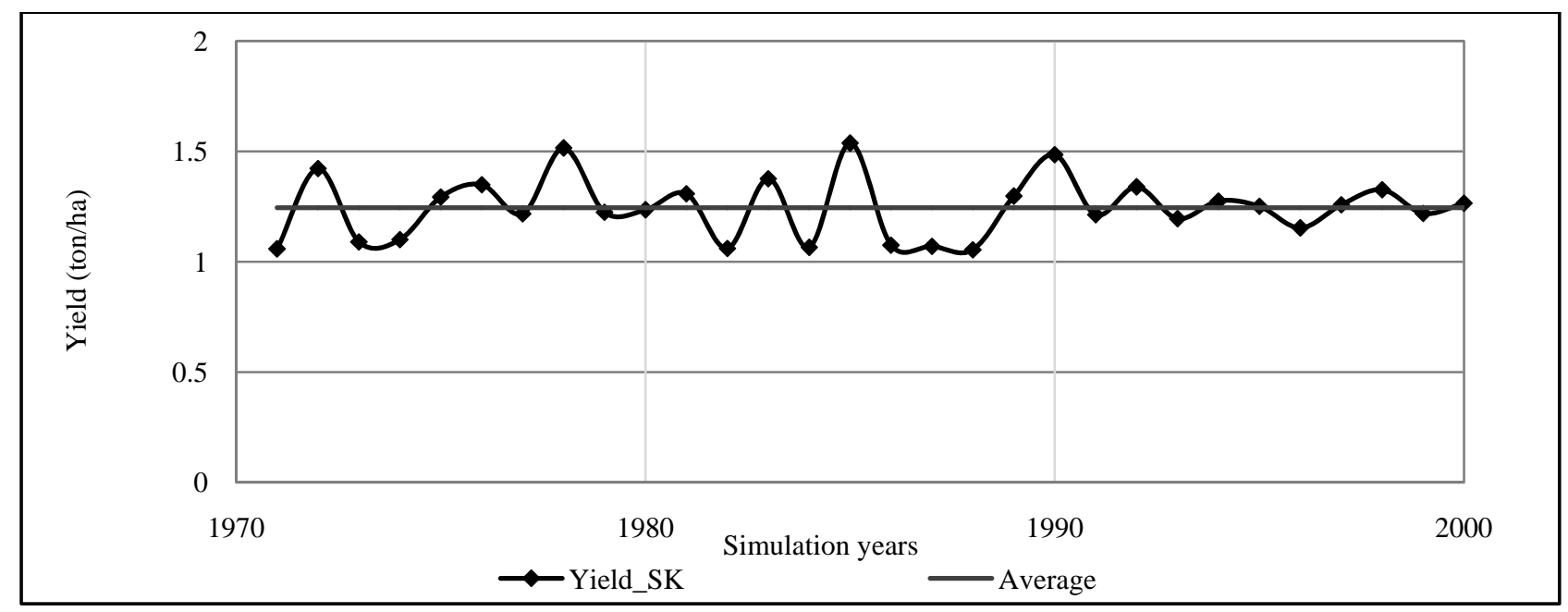

Figure 3. Pasture Yield Forecast Under Baseline Scenario in Pincher Creek Study Site. 


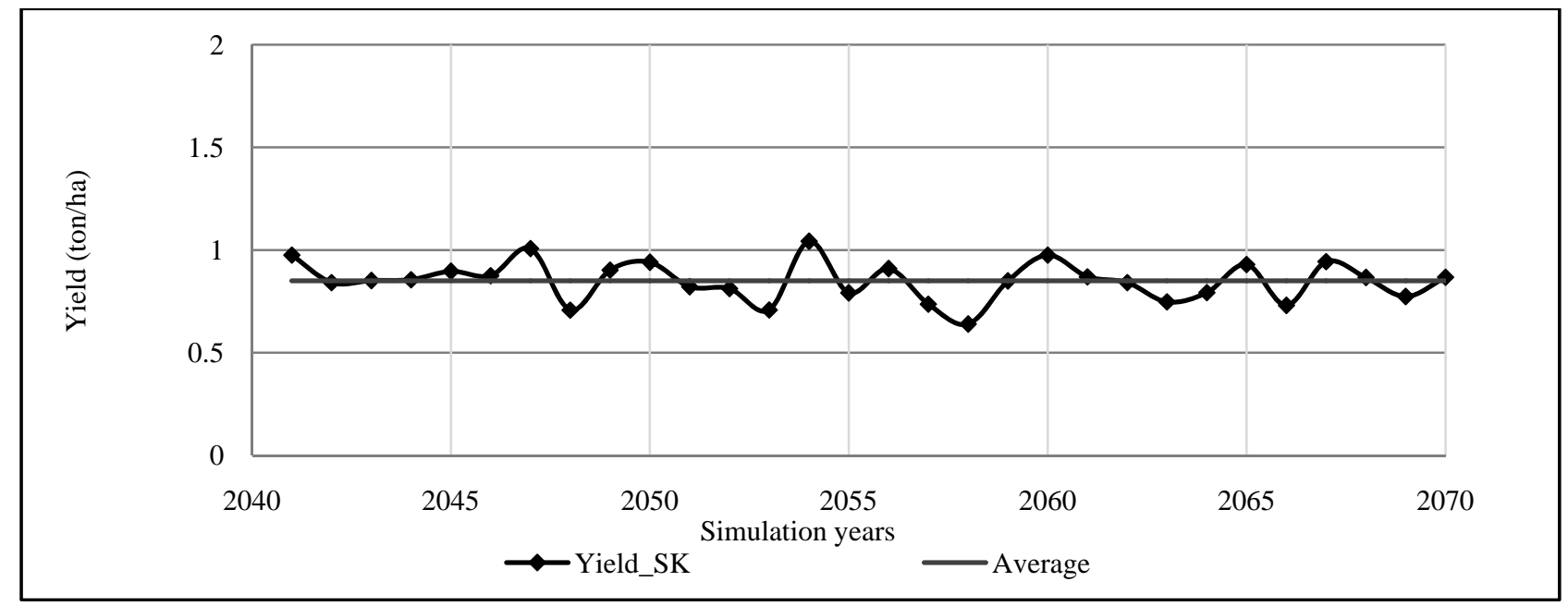

Figure 4. Pasture Yield Forecast Under Baseline Scenario in Pincher Creek Study Site.

and $30 \%$ in Swift Current, in comparison to 30-year average in baseline period. Yearly pasture yield estimates are given in Figures 1, 2, 3, and 4.

The study made use of yearly grain, crop biomass for silage and alfalfa hay yield forecast made by using FAO's AquaCrop model by simulating the study farm characteristics. Crop model was simulated under the climate forecast of Coupled Global Climate Model Regional Climate Model A2 emission scenario (CGCM3_RCM3 A2) by Professor Stefan W. Kienzle at the University of Lethbridge. Crops yields under future scenario were projected to increase in the range of $50 \%$ to more than $100 \%$ depending on crops for Pincher Creek and about $100 \%$ for all the crops in Swift Current from the baseline scenario.

\section{Beef Cattle Herd Simulation}

Beef cattle herd simulation started with the cattle inventory. Common beef cattle management practices of the prairies described by Beauchemin et al. (2010), Modongo (2014), and Koeckhoven (2008) were simulated. It is assumed that calving is done in the late February to early March. The weaning is done at seven months (at the end of September). The weaned calves enter backgrounding lot in October and backgrounding is done until February (for five months). The backgrounder enters into finishing lot in March and finisher is sold for slaughtering in June. Generally speaking, cows come into here after 3 months of calving, resulting in conception between mid-May and mid-June. Pregnancy test is done within three months of conception and open cows starting from old age are culled. In the simulation, the last calving was on 29th year and all the cows were culled after the weaning of the last lot of calves. The study assumed $88 \%$ conception rate of cows, therefore $12 \%$ open cows were replaced every year. Calving rate is assumed $98 \%$. Death losses are assumed as 5\% before weaning, $2 \%$ in backgrounding and $2 \%$ in feedlot. Gender ratio of calves is assumed 1:1. Average Daily Gain (ADG) varies with the expected finishing weight and length of feeding. Assumption on expected finishing weight, length of feeding, and average daily weight gain was taken from various sources including Beauchemin et al. (2010), MAFRI (Manitoba Agriculture Food and Rural Initiative) (2010), Larson (2011), and Modongo (2014). Mature cows and bulls are assumed as 0 ADG; ADG before weaning, backgrounding, and finishing lots was assumed as 2.2, 2.5 , and $3 \mathrm{lbs}$, respectively.

It was assumed that the producer selected superior female calves for herd replacement to maintain same 
herd size. Service bulls were replaced after five services. After the servicing at 28th year, the bulls were sold without replacement. Superior male calves were also assumed to be retained as service bulls.

Beauchemin et al. (2010)'s diet plan was adopted in this study. Throughout the simulation, new born calves were fed with cow's milk and good quality hay until the age of two months, and then calves were fed on cow's milk supplemented by summer grazing until weaning in September (at the end of seven months). Breeding cows and bulls completely depended on grazing from May until October for a period of 184 days and then fed with hay supplemented by salt and minerals until April (for 181 days). Backgrounders were put into high forage diet comprising of $60 \%$ hay and $40 \%$ grain for 151 days with 2.5 pound weight gain per day, and finishers were put on high grain diet with $80 \%$ grain and $20 \%$ silage with 3 pound weight gain per day. Nutrient recommendations of NRC (National Research Council) (2000) and Parish and Rhinehart (2009) were adopted in this study.

\section{Feed Demand and Supply}

Pasture demand was calculated based on dry matter (DM) requirements of the cows and bulls in the herd. According to AARD (1998), on average a 1,000-pound beef cow requires 26 pounds DM a day, which is called an Animal Unit Equivalent (AUE). Total pasture requirement of the grazing animal for the entire grazing months, expressed in terms of Animal Unit Month (AUM), was calculated as in equation (1):

$$
\begin{aligned}
\text { AUM }=\text { AUE } * \text { Number of Animal } & \\
& * \text { Months in grazing }
\end{aligned}
$$

Pasture supply, also expressed in terms of AUM/acre, from a given pasture land was calculated to match the pasture demand. Consideration of carrying capacity (CC) of the pasture land is important as ecologically sustainable stocking rate (ESSR) represents the maximum number of AUMs that can be placed without causing negative effect of rangeland health (Adams et al. 2003). ESSR of given pasture land was calculated as shown in equation (2). For the average pasture productivity of 1960 to 1991 period, the choice of $35 \%$ utilization rate gave the observed ESSR for both the study sites. Therefore, 35\% utilization rate and yearly pasture yield as in equation (2) were used to calculate yearly pasture supply, and total pasture land required to meet the grazing demand of the herd was calculated as shown in equation (3):

$$
\operatorname{ESSR}\left(\frac{\mathrm{AUM}}{\mathrm{acre}}\right)=\frac{\text { Yield }\left(\frac{\mathrm{kg}}{\text { acre }}\right) * \text { Utilization rate }}{455 \mathrm{~kg} / \mathrm{AUM}}
$$

Pastureland required (acre) $=\frac{\text { AUM demand }}{\text { Stocking rate }\left(\frac{\mathrm{AUM}}{\mathrm{acre}}\right)}$

The farm is assumed to have established alfalfa hay. Similar to pasture demand, hay demand was also calculated to fulfill the daily DM requirement of an animal. The DM required per day for different animal type depends on weight, age, and ADG; these were obtained from Parish and Rhinehart (2009). Hay was established at the first year of simulations and continued maintaining and harvesting until the end of 7th production year (MAFRI 2015). New establishment was done at beginning of every 8th year and four establishments in total for the 30 years simulation period.

Feed grain and silage demand and on-farm supply were linked by formulating least cost linear programming problem. This was done to minimize total feed production costs suggested by Visagie and Ghebretsadik (2005). Feed grain and silage demand of the beef cattle herd was calculated to satisfy their nutrient requirements. FAO's AquaCrop model was used to estimate grain and crop biomass production. An average 10-year silage yield for the period of 2002 to 2010 obtained from AAF (Alberta Agriculture and 
Forestry) (2013) was considered as an average silage yield for baseline period for both the study sites. Percentage change in baseline and future biomass estimated from AquaCrop model was applied to the average baseline silage yield to estimate average future silage yield. Yearly variation in biomass yield estimated by AquaCrop model is then applied to the average estimates to generate yearly values.

\section{WHOLE FARM BUDGETING}

Commodity price and variable cost of production were estimated from historical series using time series models combined with Monte-Carlo simulations ${ }^{1}$. Historical commodity prices and cost of production (COPs) for 1971 to 2000 were used to forecast the cost and price for 1971-2000 period and 2041-2070 period for the baseline and future scenario simulation in this study. Missing information was estimated using Farm Product Price Index (FPPI) for price (Statistics Canada 2014a) and Farm Input Price Index (FIPI) for COP estimate (Statistics Canada 2014b). Commodity prices for Saskatchewan were obtained from Government of Saskatchewan (2014) and SAF (Saskatchewan Agriculture and Food) (2000), and prices for Alberta were obtained from AARD (2014b). COP benchmark estimates were obtained from SMA (2013), G. Payne (personal communication, December 10, 2013), J. Wood (personal communication, 2013), AARD (2013), and MAFRI (2010; 2012; 2013a; 2013b; 2013c). Crop cost of production for brown soil zone was used for Swift Current site, and cost of production for black soil zone was used for Pincher Creek.

Capital base of similar sized mixed farms in the prairies obtained from K. Larson (personal communication, 2014) was used to estimate the capital cost for the study farms. Similar approach of creating 1971-2000 series using FIPI and forecasting them for two simulation periods using time series models was used in capital cost forecast.

\section{Climate Extremes, and Grain and Cattle Feed Price}

Quiggin (2012) and Schiere and Pang (2014) said that grain and meat products are part of integrated global markets, and reduced supply due to droughts can be countered by the supply from other countries. They further said that analysis to disentangle the drought effect is complicated because other factors like changes in energy price also have significant impact on global food price. Therefore, this analysis assumes that the grain and beef prices follow global phenomenon and there is no significant impact of local drought on commodity prices. However, evidence shows that local hay and feed barley price increased during major Canadian drought events. Feed barley price rose by more than $35 \%$ and hay price rose by more than $50 \%$ during 2002 droughts in both the Alberta and Saskatchewan. To reflect the impacts of extreme events on local feed prices, estimated feed prices were manipulated to reflect the average price increase during three major Canadian droughts events of 1988-1989, 2001-2002, and 2009-2010. Estimated feed prices were manipulated so that the feed barley prices during the drought events were at least 13\% higher and hay prices were at least $17 \%$ higher in Swift Current and 22\% higher in Pincher Creek from their last five-year average.

\section{Study Scenarios and Adaptation Alternatives}

As discussed earlier, impacts of climate extremes under both the baseline and future scenario were linked through the yield effect on crops, hay and pasture productivities. The resource base (hay and pastureland) of the farm at the start of the simulation was set in such a manner that their supply and demand match exactly in an average year. The main link of extreme events on beef herd is considered through the impact on pasture productivity affecting carrying capacity of pasture land. It is assumed that impact of extreme events determines the number of beef head 
Table 1. Scenarios and Adaptation Description

\begin{tabular}{lllll}
\hline Period & Climate & Economy/Price & Beef herd adaptation & Crop activity adaptation \\
\hline \multirow{2}{*}{ Baseline } & $1971-2000$ & $1971-2000$ & Purchase feed & Crop mix selection \\
scenario & $1971-2000$ & $1971-2000$ & Changes in management & Crop mix selection \\
& $1971-2000$ & $1971-2000$ & Cull herd & Crop mix selection \\
\hline \multirow{2}{*}{ Future } & $2041-2070$ & $2041-2070$ & Purchase feed & Crop mix selection \\
scenario & $2041-2070$ & $2041-2070$ & Changes in management & Crop mix selection \\
& $2041-2070$ & $2041-2070$ & Cull herd & Crop mix selection \\
\hline
\end{tabular}

which the pastureland can sustain during summer. Therefore, the adaptation alternatives: purchase feed, changes in management, and cull herd, deal with only summer pasture deficit. More feed shortages after adopting adaptation alternatives are fulfilled by purchasing feed regardless of what adaptation was done in managing summer pasture deficit. Scenario descriptions are given in Table 1.

The adaptations in beef herd either maintain the supply of feed by purchasing or reduce the feed demand of the herd to adapt to climate change and extremes. Under Adaptation 1, beef herd size and feeding amount are maintained by purchasing extra feed to match summer pasture deficit. Adaptation 2, reduces the amount of feed given to beef herd by early weaning of calves to reduce pasture demand of cow and limit feeding of feedlot animals to reduce the hay and grain demand. Under Adaptation 3, herd size is reduced to match the pasture demand and supply.

\section{RESULTS AND DISCUSSIONS}

\section{Feed Shortages, Beef Sold, and Cost of Feed Production}

Frequency and severity of the impact on pasture production determines the cost of beef herd management and thus the farm financial position during climate extreme events. The results showed that frequency of pasture deficit increases under future scenario as shown in Table 2. About half of the years in 30-year simulation periods have pasture shortages under baseline periods, which increases to 20 years in Pincher Creek and almost entire simulation years in Swift Current under the future scenario. The Swift Current farm is expected to suffer relatively frequent summer pasture deficit largely due to already lower pasture productivity and relatively drier climate projected under the future scenario.

The average live weight sold under different adaptation alternatives is shown in Table 3 and Table 4. Highest live weight cattle sold would be achieved under purchase feed strategy. Under purchase feed strategy, herd size is maintained and no compromise is done in feeding amount. Changes in management strategy make a compromise on feeding amount that has impacts on daily live weight gain of cattle, and cull herd strategy reduces the average herd size resulting in lower output.

Proportion of cost of feed production to total variable cost of beef cattle production under the baseline scenario is estimated about $40 \%$ in Pincher Creek and about $42 \%$ in Swift Current with little variation across adaptation. If the herd size is maintained with regular feeding plan, average yearly feed production cost in Pincher Creek is estimated to be $\$ 17,000$, which would double to $\$ 34,000$ under the future scenario. In Swift Current, it is estimated to be $\$ 18,000$ /year under baseline and increase by more than $80 \%$ to $\$ 33,000$ year under the future scenario. In Picher Creek, cost of feed production under changes in management strategy is 
Table 2. Number of Years of Feed Shortages and Cost of Feed Purchase

\begin{tabular}{ll}
\hline Periods & Pasture shortage (no of years) \\
\hline Baseline period & \\
Pincher Creek & 16 \\
Swift Current & 14 \\
Future period & \\
Pincher Creek & 20 \\
Swift Current & 28 \\
\hline
\end{tabular}

Table 3. Number and Live Weight Beef Sold, Pincher Creek, Alberta

\begin{tabular}{lll}
\hline Scenarios & $\begin{array}{l}\text { Live weight cattle } \\
\text { sold ('000 lb/year) }\end{array}$ & CV \\
\hline Base scenario & & .07 \\
\hline Purchase feed & 102.97 & .17 \\
Changes in management & 81.45 & .25 \\
Cull herd & 84.39 & \\
\hline Future scenario & & .07 \\
\hline Purchase feed & 102.97 & .17 \\
Changes in management & 81.45 & .24 \\
Cull herd & 77.97 & \\
\hline
\end{tabular}

Table 4. Number and Amount of Beef Sold, Swift Current, Saskatchewan

\begin{tabular}{lll}
\hline Scenarios & $\begin{array}{l}\text { Live weight finisher } \\
\text { sold ('000 lb/year) }\end{array}$ & CV \\
\hline Base scenario & & .13 \\
\hline Purchase feed & 87.43 & .20 \\
Changes in management & 69.51 & .22 \\
Cull herd & 76.66 & \\
\hline Future scenario & & .13 \\
\hline Purchase feed & 87.43 & .20 \\
Changes in management & 69.51 & .30 \\
Cull herd & 41.84 & \\
\hline
\end{tabular}

almost similar to that of purchase feed strategy under both the scenarios. The cost of feed production decreased by $7 \%$ and $5 \%$ under baseline and future scenario respectively, under cull herd strategy. In Swift Current under both scenarios, cost of feed production is similar for both the purchase feed strategy and changes in management strategy. In comparison to purchase feed strategy, cost of feed production under cull herd decreased by $5 \%$ under baseline and about $11 \%$ under future scenario.

Cost of on-farm feed production does not vary much across adaptation alternatives. Output marketed, however, is highly variable across the adaptation strategy. These results imply that the impact of the beef herd adaptation strategy affects the farm profit more through the impacts on output rather than cost.

\section{Profitability Analysis}

Beef farm profitability varies across the choice of adaptation strategies undertaken. Total gross margin (GM) discounted at present value for 30-year simulation period and average annual GM for three alternative 
Table 5. Gross Margin From Beef Cattle Activities Under the Baseline and the Future Scenario Pincher Creek Study Site

\begin{tabular}{llllll}
\hline Adaptation alternatives & $\begin{array}{l}\text { GM } \\
\left(\mathrm{PV},{ }^{\prime} 000 \$\right)\end{array}$ & \% of purchase feed & \% of baseline & $\begin{array}{l}\text { Average } \\
\text { ('000 \$/year) }\end{array}$ & CV \\
\hline Baseline scenario & & & & 45.75 & .36 \\
\hline Purchase feed & 633.86 & & 31.07 & .64 \\
Changes in management & 416.23 & 65.67 & & 38.70 & .47 \\
Cull herd & 527.98 & 83.30 & & 67.33 & .29 \\
\hline Future scenario & & & 150.03 & .67 \\
\hline Purchase feed & 950.98 & & 126.84 & 41.44 & .57 \\
Changes in management & 527.97 & 55.52 & 124.69 & 46.21 & \\
Cull herd & 658.36 & 69.23 & & & \\
\hline
\end{tabular}

Table 6. Gross Margin From Beef Cattle Activities Under the Baseline and the Future Scenario Swift Current Study Site

\begin{tabular}{|c|c|c|c|c|c|}
\hline Adaptation alternatives & $\begin{array}{l}\text { GM } \\
\text { (PV, '000\$) }\end{array}$ & $\%$ of purchase feed & $\%$ of baseline & $\begin{array}{l}\text { Average } \\
\text { ('000\$/year) }\end{array}$ & $\mathrm{CV}$ \\
\hline \multicolumn{6}{|l|}{ Base scenario } \\
\hline Purchase feed & 395.07 & & & 29.54 & .36 \\
\hline Changes in management & 247.47 & 62.64 & & 19.13 & .64 \\
\hline Cull herd & 265.38 & 67.17 & & 20.39 & .47 \\
\hline \multicolumn{6}{|l|}{ Future scenario } \\
\hline Purchase feed & 553.69 & & 140.15 & 44.49 & .29 \\
\hline Changes in management & 216.60 & 39.12 & 87.52 & 21.58 & .67 \\
\hline Cull herd & 64.99 & 11.74 & 24.49 & 5.26 & .57 \\
\hline
\end{tabular}

beef herd adaptation strategies is presented in Table 5 and Table 6.

The results showed that the highest GM is generated if the herd size is maintained with regular feeding plan by purchasing additional feed to manage the feed shortages during the period of extreme climate events under both the baseline and future scenario in both the study sites. In comparison to purchase feed strategy, the GM under cull herd strategy decreased by more than $17 \%$ in the Pincher Creek and 33\% in Swift Current under baseline scenario. The GM decreased by more than $35 \%$ in Pincher Creek and more than $38 \%$ in Swift Current if the changes in management strategy is adopted to deal with the effect of extreme climate events under the baseline scenario. Economic impact of climate change on beef cattle production is estimated to increase in the range of $24 \%$ to $50 \%$ from the baseline scenario depending on the choice of adaptation strategy. Similar to the baseline scenario results, purchasing additional feed to deal with the feed shortages is identified superior strategy under the future scenario also. The superiority of this strategy is also supported by very low income risk in comparison to other two strategies as indicated by the lowest coefficient of variation.

In spite of significant impact on pasture production with frequent event of feed shortages and increasing feed production cost, beef activity in the future can still be a profitable enterprise. The gain from beef production, however, is dependent on choice of strategy in dealing with feed shortages among many other factors. Table 7 summarizes the net gain by adopting purchase feed strategy over changes in management and cull herd strategy. 
Table 7. Comparison of Adaptation Options Under the Baseline and Future Scenario in the Two Study Farms

\begin{tabular}{lcc}
\hline Comparisons of strategies & $\begin{array}{l}\text { Pincher Creek } \\
\text { ('000 \$, PV) }\end{array}$ & $\begin{array}{l}\text { Swift Current } \\
\text { ('000 \$, PV) }\end{array}$ \\
\hline Baseline scenario & 105.88 & 129.69 \\
Gain of purchase feed over cull herd strategy & 217.63 & 147.59 \\
Gain of purchase feed over change in management strategy & & 488.70 \\
Future scenario & 292.21 & 337.10 \\
Gain of purchase feed over cull herd strategy & 422.76 & \\
Gain of purchase feed over change in management strategy & & \\
\hline
\end{tabular}

Table 8. Percentage Change in Farm Profitability and liquidity Under Alternative Adaptation Strategies Relative to Reference Adaptation in Pincher Creek

\begin{tabular}{|c|c|c|c|c|c|}
\hline \multirow[b]{2}{*}{ Changes } & \multicolumn{3}{|c|}{ Profitability } & \multirow{2}{*}{$\begin{array}{l}\text { Liquidity } \\
\text { Average farm cash } \\
\text { flow }\end{array}$} & \multirow{2}{*}{$\begin{array}{l}\text { Net worth } \\
\text { Net worth at exit } \\
\text { (excluding land) }\end{array}$} \\
\hline & $\begin{array}{l}\text { Beef cattle } \\
\text { activities (GM) }\end{array}$ & $\begin{array}{l}\text { Crop activities } \\
\text { (GM) }\end{array}$ & $\begin{array}{l}\text { Whole farm } \\
\text { profit }\end{array}$ & & \\
\hline \multicolumn{6}{|l|}{ Baseline scenario } \\
\hline $\begin{array}{l}\text { Changes under "changes in } \\
\text { mangement" from purchase } \\
\text { feed }\end{array}$ & $-34.33 \%$ & $+6.16 \%$ & $-26.88 \%$ & $-20.21 \%$ & $-39.94 \%$ \\
\hline $\begin{array}{l}\text { Changes under "cull herd" } \\
\text { from purchase feed }\end{array}$ & $-16.17 \%$ & $+23 \%$ & $+1.65 \%$ & $+.50 \%$ & $+.03 \%$ \\
\hline \multicolumn{6}{|l|}{ Future scenario } \\
\hline $\begin{array}{l}\text { Changes under "changes in } \\
\text { mangement" from purchase } \\
\text { feed }\end{array}$ & $-44.48 \%$ & $+2.22 \%$ & $-29.49 \%$ & $-21.57 \%$ & $+.06 \%$ \\
\hline $\begin{array}{l}\text { Changes under "cull herd" } \\
\text { from purchase feed }\end{array}$ & $-30.77 \%$ & $+7.53 \%$ & $-.16 \%$ & $-7 \%$ & $-6.04 \%$ \\
\hline
\end{tabular}

Table 9. Percentage Change in Farm Profitability and Liquidity Under Alternative Adaptation Strategies Relative to Reference Adaptation in Swift Current

\begin{tabular}{|c|c|c|c|c|c|}
\hline \multirow[b]{2}{*}{ Changes } & \multicolumn{3}{|c|}{ Profitability } & \multirow{2}{*}{$\begin{array}{l}\text { Liquidity } \\
\text { Average farm cash } \\
\text { flow }\end{array}$} & \multirow{2}{*}{$\begin{array}{l}\text { Net worth } \\
\text { Net worth at exit } \\
\text { (excluding land) }\end{array}$} \\
\hline & $\begin{array}{l}\text { Beef cattle } \\
\text { activities (GM) }\end{array}$ & $\begin{array}{l}\text { Crop activities } \\
\text { (GM) }\end{array}$ & $\begin{array}{l}\text { Whole farm } \\
\text { profit }\end{array}$ & & \\
\hline \multicolumn{6}{|l|}{ Baseline scenario } \\
\hline $\begin{array}{l}\text { Changes under "changes in } \\
\text { mangement" from purchase } \\
\text { feed }\end{array}$ & $-37.36 \%$ & $+4.93 \%$ & $-13.73 \%$ & $-12.22 \%$ & $-32.68 \%$ \\
\hline $\begin{array}{l}\text { Changes under "cull herd" } \\
\text { from purchase feed }\end{array}$ & $-38.85 \%$ & $+16.75 \%$ & $+2.51 \%$ & $+2.70 \%$ & $+.70 \%$ \\
\hline \multicolumn{6}{|l|}{ Future scenario } \\
\hline $\begin{array}{l}\text { Changes under "changes in } \\
\text { mangement" from purchase } \\
\text { feed }\end{array}$ & $-60.88 \%$ & $+.55 \%$ & $-10.45 \%$ & $-9.73 \%$ & $-5.56 \%$ \\
\hline $\begin{array}{l}\text { Changes under "cull herd" } \\
\text { from purchase feed }\end{array}$ & $-88.26 \%$ & $+10.82 \%$ & $+1.58 \%$ & -4.40 & $+1.12 \%$ \\
\hline
\end{tabular}




\section{Impact of Beef Herd Adaptation Strategy at Crop and Whole Farm Revenue}

Profitability analysis of beef cattle production activities discussed in earlier section showed that purchase feed strategy is superior in dealing with climate extreme events. However, it is also important to understand the impact of beef cattle herd adaptation strategy at crop and whole farm level in selecting the strategy in mix-farm setting. Taking purchase feed strategy as reference case, impacts of adopting changes in management strategy and cull herd strategy at beef cattle production, crop production, and at whole farm level are shown in Table 8 and Table 9.

In both the study sites under both the baseline and the future scenarios, purchase feed strategy is superior to other strategies. At crop production activities, both the changes in management and cull herd strategy generate higher GM as these strategies release more land from feed production to crop production for market sales. However, cull herd strategy is preferred at crop activities due to lowest feed area demand due to reduction in herd size.

At the whole farm level, the economic impacts of adopting changes in management strategy are predominantly negative in both the study sites. Overall results confirm that changes in management is not the economically preferred strategy in dealing with drought in both the study sites. Impact of adopting cull herd strategy is mix. In the Pincher Creek, cull herd strategy is preferred under baseline scenario while purchase feed is preferred under future scenario. The impact of adopting cull herd strategy is direct on amount of beef cattle sold. Beef cattle activities were dominant in the Pincher Creek farm, severe impact on beef cattle GM due to the adoption of cull herd strategy under the future scenario has negative impact at whole farm level. In the Swift Current, cull herd strategy is preferred under both the scenarios. Despite of severe impact on beef cattle activities, its effect is less evident at whole farm level as the crop activities are dominant in the Pincher Creek farm.

Analysis of the results implies that the choice of adaptations is contextual, and preference to adaptation differs across activities, farms, and climate scenarios. The share of beef revenue to total farm revenue also has profound impacts on the selection of beef herd management decision at whole farm level.

\section{CONCLUSIONS}

Canada's beef industry is the largest single commodity source of farm cash income. Alberta and Saskatchewan in particular dominate the beef cattle production in Canada. However, beef cattle production is a relatively unstudied area from the economics and risk management point of view. Canadian Prairie has witnessed severe events of climate extremes, especially the multi-years droughts causing severe impact on livestock and beef production in the past and frequency of such events is expected to increase in the future. Appropriate choice of coping strategies therefore, would be helpful in minimizing the severe impact of climate extremes during future climate extremes. The study assessed three adaptation strategies: (1) purchasing feed; (2) changes in herd management; (3) cull herd in dealing with feed shortages during extreme climate events. The study used whole farm simulation model to simulate two Canadian Prairie mixed crop and beef farms-one in Swift Current, Saskatchewan and another in Pincher Creek, Alberta. The farms are assumed to perform cow-calf as well as feed lot operations. On-farm crop production for both the beef feed and market sales was also integrated.

The cost of feed production comprises more than $40 \%$ of total beef cost of production in both the study sites. The cost of feed production is expected to 
double in the future, however, there is no significant difference in the on-farm feed production cost across different adaptation alternatives. Live weight cattle sold and farm income, however, is highly dependent on the choice of adaptation done in dealing with extreme climate events. These results suggest that the impact of the beef herd adaptation strategy affects the farm profit more through the output changes and less through cost changes. In spite of significant impact on pasture production with frequent events of feed shortages and increasing feed production cost, beef activity in the future can still be profitable, provided that appropriate stratgies for beef herd management are followed during the period of climate extremes. The highest return is generated if the herd size is maintained with regular feeding plan by purchasing additional feed. Choice of beef herd management strategy in dealing with climate extremes would have significant impact on crop production and at whole farm level in mix-farm settings. The choice is dependent on many factors such as: existing carrying capacity of grazing, existing feeding cost, severity of climate extremes, and integration of crop and beef cattle production, as well as importance of beef enterprise on the farm, among others.

Beef cattle activities can be vulnerable due to projected decrease in pasture carrying capacity and frequent events of feed shortages in the future. Canadian agriculture policy on risk management called Business Risk Management (BRM), however, is not clear on how it covers any productivity or output decline in livestock sector. Only risk management program in livestock is Western Livestock Price Insurance Program (WLPIP) which protects farmers from price declines. No such climate risk reduction programs are available. Therefore, expansion of existing agriculture policy to cover climate risk in beef production is necessary. Also, policy to support farmers in making appropriate choice of strategy in dealing with climate extremes would also bring forth desired adaptation to climate change.

\section{Acknowledgements}

The authors are very thankful for the financial support received from the VACEA (Vulnerability and Adaptation to Climate Extremes in the Americas) project, funded by the International Development Research Center, through the University of Regina.

\section{Note}

1. Monte-Carlo simulation of the time series model was for the maximum likelihood estimation of the coefficients. For this "fully specified parametric model" simulation process suggested by Davidson and Mckinnon (2004) as outlined in Adkins and Gade (2012) was followed. This study followed the process with estimated values of $\beta$ coefficients and, real values of Xs and estimated variance with the assumption of normal distribution. The simulation was conducted for 1,000 iteration.

\section{References}

AAF (Alberta Agriculture and Forestry). 2013. Alberta 2011 Greenfeed and Silage Production Survey Results. Retrieved May 25, 2015 (http://www1.agric.gov.ab.ca/\$department/ deptdocs.nsf/all/sdd14009).

AAFC (Agriculture and Agri-Food Canada). 2013. Lessons Learned From the Canadian Drought Years 2001 and 2002. Retrieved July 25, 2015 (http://www.agr.gc.ca/eng/?id= 1326987176314).

- 2014. Cattle Inventory by Farm Type. Retrieved July 25, 2015 (http://www.agr.gc.ca/eng/industry-markets-and-trade /statistics-and-market-information/by-product-sector/red-m eat-and-livestock/red-meat-market-information-canadian-in dustry/by-sector-reports/cattle-and-calves/cattle-inventoryby-farm-type/?id=1415860000074).

AARD (Alberta Agriculture and Rural Development). 1998. Grazing Tame Pastures Effectively. Retrieved July 3, 2014 (http://www1.agric.gov.ab.ca/\$department/deptdocs.nsf/all/ agdex113?opendocument).

- 2011. Range and Pasture Management When Dealing With Drought. Retrieved April 2, 2014 (http://www1.agric. gov.ab.ca/\%24department/deptdocs.nsf/all/agdex136).

- 2013. Agriprofit\$ Benchmark Analysis. Agriprofit\$ Crop and Beef Economics for 2013. Retrieved (http://www1. agric.gov.ab.ca/\$department/newslett.nsf/homemain/agrp).

- 2014a. Range and Pasture Management When Dealing With Drought. Retrieved April 2, 2014 (http://www1.agric. gov.ab.ca/\$department/deptdocs.nsf/all/agdex136?opendoc ument). 
- 2014b. Agriculture Statistics Year Book 2013. Retrieved November 20, 2014 (http://www1.agric.gov.ab.ca/ \$department/deptdocs.nsf/all/sdd15054/\$file/2013-yearboo k.pdf).

Adams, B. W., R. Ehlert, D. Moisey, and R. L. McNeil. 2003. "Rangeland Plant Communities and Range Health Assessment Guidelines for the Foothills Fescue Natural Sub-region of Alberta.” Rangeland Management Branch, Public Lands Division, Alberta Sustainable Resource Development, Lethbridge, Pub. No. T/038 85.

Adkins, L. C. and L. M. Gade. 2012. Monte Carlo Experiment Using Stata: A Primer With Examples. Retrieved January 12, 2015 (http://www.learneconometrics.com/pdf/MCstata/ MCstata.pdf).

Barrow, E. 2009. Climate Scenarios for Saskatchewan. Prairie Adaptation Research Collaborative. Retrieved January 16, 2013 (http://www.parc.ca/pdf/research_publications/ summary_docs/sd2009-01.pdf).

Bastian, C. T., S. Mooney, A. M. Nagler, J. P. Hewlett, S. I. Paisley, M. A. Smith, W. M. Frasier, and W. J. Umberger. 2006. "Ranchers Diverse in Their Drought Management Strategies.” Western Economics Forum 5(2):1-8.

Beauchemin, K. A., H. H. Janzen, S. M. Little, T. A. McAllister, and S. M. McGinn. 2010. "Life Cycle Assessment of Greenhouse Gas Emissions From Beef Production in Western Canada: A Case Study.” Agricultural Systems 103(6):371-379.

Belasco, E. J., Y. Cheng, and T. C. Schroeder. 2015. "The Impact of Extreme Weather on Cattle Feeding Profits.” Journal of Agricultural and Resource Economics 40(2):285-305.

Bonsal, B. R., R. Aider, P. Gachon, and S. Lapp. 2013. “An Assessment of Canadian Prairie Drought: Past, Present, and Future.” Climate Dynamics 41(2):501-516.

Davidson, R. and J. G. MacKinnon. 2004. Econometric Theory and Methods. New York: Oxford University Press.

DEPI (Department of Environment and Primary Industries). 2014. Drought Feeding for Cattle: Controlled Weight Loss Program. State Government Victoria. Retrieved June 26, 2013 (http://www.dpi.vic.gov.au/agriculture/farming-man agement/drought-information/drought-feeding-for-cattle/ch apter-3).

Foran, B. D. and D. M. S. Smith. 1991. "Risk, Biology and Drought Management Strategies for Cattle Stations in Central Australia.” Journal of Environmental Management 33(1):17-33.

Gillard, P. and R. Moneypenny. 1990. “A Decision Support Model to Evaluate the Effects of Drought and Stocking Rate on Beef Cattle Properties in Northern Australia.” Agricultural Systems 34(1):37-52.

Government of Saskatchewan. 2014. Agriculture Statistics.
Retrieved (http://www.agriculture.gov.sk.ca/Statistics).

IISD (International Institute for Sustainable Development). 1997. "Agriculture and Climate Change: A Prairie Perspective.” International Institute for Sustainable Development and Environmental Adaptation Research Group, Institute of Environmental Studies, University of Toronto.

Khandekar, M. L. 2004. "Canadian Prairie Drought: A Climatological Assessment." Prepared by Madhav L. Khandekar, Consulting Meteorologist, for Alberta Environment.

Koeckhoven, S. 2008. "Economics of Agricultural Best Management Practices in the Lower Little Bow Watershed.” M.S. dissertation, Department of Rural Economy, University of Alberta.

Kulshreshtha, S. N. 2012. "Economic Impacts of Livestock Production in Canada-A Regional Multiplier Analysis.” Report prepared for Canfax Research Services Canadian Cattlemen's Association, Department of Bioresource Policy, Business and Economics, University of Saskatchewan. Retrieved (http://albertabeef.org/uploads/ TheMultiplierEffectfortheCanadianCattleIndustry00110254.pdf).

Larson, K. 2011. 2010 Saskatchewan Cow-Calf Cost of Production Analysis. Western Beef Development Center. Retrieved (http://www.wbdc.sk.ca/pdfs/fact_sheets/2011/ 2010\%20COP\%20Fact\%20Sheet_WBDC_Larson.pdf).

MAFRI (Manitoba Agriculture Food and Rural Initiative). 2010. Guideline for Estimating Beef Feedlot Finishing Cost 2010. Ministry of Agriculture Food and Rural Initiative, Manitoba. Retrieved September 21, 2013 (http://www. manitoba.ca/agriculture).

- 2012. Guideline for Estimating Beef Feedlot Finishing Cost 2012. Ministry of Agriculture Food and Rural Initiative, Manitoba. Retrieved September 21, 2013 (http://www. manitoba.ca/agriculture).

_. 2013a. Guideline for Estimating Beef Feedlot Finishing Cost 2013. Ministry of Agriculture Food and Rural Initiative, Manitoba. Retrieved May 4, 2014 (http://www. manitoba.ca/agriculture).

_ 2013b. Cost of Production. Ministry of Agriculture Food and Rural Initiative, Manitoba. Retrieved May 4, 2014 (http://www.manitoba.ca/agriculture).

- 2013c. Guideline for Estimating Cow-Calf Production Costs 2013. Ministry of Agriculture Food and Rural Initiative, Manitoba. Retrieved May 4, 2014 (http://www. manitoba.ca/agriculture).

- 2015. Guidelines for Estimating Hay Production Costs. Retrieved May 12, 2015 (http://www.gov.mb.ca/ agriculture/business-and-economics/financial-management/ pubs/cop_forage_alfalfahay.pdf). 
Modongo, O. 2014. "Economics of Greehouse Gas Mitigation Scenarios in Beef Production." Master dissertation, University of Saskatchewan.

Nagler, A. M., C. T. Bastian, J. P. Hewlett, S. Mooney, S. I. Paisley, M. A. Smith, W. M. Frasier, W. J. Umberger, and P. Ponnameneni. 2007. "Multiple Impacts-Multiple Strategies: How Wyoming Cattle Producers Are Surviving in Prolonged Drought." University of Wyoming Cooperative Extension Service, College of Agriculture, University of Wyoming, Laramie. Retrieved (http://www.uwagec.org/ farmmgt/PUBS/B1178.pdf).

NRC (National Research Council). 2000. Nutrient Requirement of Beef Cattle: Seventh Revised Edition: Update 2000. Subcommittee on Beef Cattle Nutrition, Committee on Animal Nutrition, Board on Agriculture, NRC, Canada. USA: National Academies Press.

OMAFRA (Ontario Ministry of Agriculture Food and Rural Affairs). 2012. Dealing With Feed Shortages on Your Beef Farm. Ontario Ministry of Agriculture and Food Government of Ontario, Canada. Retrieved July 24, 2014 (http://www.omafra.gov.on.ca/english/livestock/beef/facts/f eedshort.html).

Paimazumder, D., L. Sushama, R. Laprise, M. N. Khaliq, and D. Sauchyn. 2013. "Canadian RCM Projected Changes to Short- and Long-Term Drought Characteristics Over the Canadian Prairies.” International Journal of Climatology 33(6):1409-1423.

Parish, J. and J. Rhinehart. 2009. Beef Cattle Nutrient Requirement. Mississippi State University Extension Services. Publication 2528. Retrieved August 24, 2013 (http://msucares.com/pubs/publications/p2528.pdf).

Parsons, D., C. F. Nicholson, R. W. Blake, Q. M. Ketterings, L. Ramírez-Aviles, J. H. Cherney, and D. G. Fox. 2011. "Application of a Simulation Model for Assessing Integration of Smallholder Shifting Cultivation and Sheep Production in Yucatán, Mexico.” Agricultural Systems 104(1):13-19.

Price, D. T., D. W. McKenney, L. A. Siltanen, R. M. Papadpol, and K. Lawrence. 2011. High-Resolution Interpolation of Climate Scenarios for Canada Derived From General Circulation Model Similations. Edmonton, Alberta: Northern Forestry Centre, Canadian Forest Service.

Quiggin, J. 2012. Drought Climate Change and Food Prices in Australia. School of Economics and School of Political Science and International Studies, University of Queensland. Retrieved July 28, 2013 (https://www. acfonline.org.au/sites/default/files/resources/Climate_chang e_and_food_prices_in_Australia.pdf).

Rasby, R. 2013. Managing Cow Herd During Drought. UNL Beef, University of Nebraska Lincoln. Retrieved July 21, 2013 (http://beef.unl.edu/cattleproduction/cowherdsdroug ht).

Ritten, J. P., C. T. Bastian, W. M. Frasier, S. I. Paisley, and M. A. Smith. 2011. "Two Common Drought Management Strategies and Some Considerations for Wyoming Cattle Producers.” University of Wyoming Cooperative Extension Service, College of Agriculture, University of Wyoming, Laramie. Bulletin B-1218.

Rowlinson, P. 2008. "Adapting Livestock Production Systems to Climate Change-Temperate Zones.” Presented at Livestock and Global Change Conference, May 2008, Tunisia.

SAF (Saskatchewan Agriculture and Food). 2000. Agriculture Statistics Year Book of 2000. Regina, Saskatchewan: Statistics Branch.

Schreier, H. and G. Pang. 2014. Impacts of Increased Climatic Variability. Faculty of Land and Food Systems, University of British Columbia. Retrieved June 2, 2015 (http://wmc. landfood.ubc.ca/webapp/VWM/course/impacts-of-increase d-climatic-variability/recent-examples/).

Seo, S. N. and R. Mendelsohn. 2007. The Impact of Climate Change on Livestock Management in Africa: A Structural Ricardian Analysis. Washington, D.C.: World Bank.

SMA (Saskatchewan Ministry of Agriculture). 2008. Feeding Livestock During Feed Shortages. Saskatchewan Ministry of Agriculture. Retrieved April 2, 2013 (http://www. agriculture.gov.sk.ca/default.aspx?dn=e05fd8c9-ff22-44c79500-ad1619cdc7f6).

—. 2013. Crop Planning Guide 2013. Saskatchewan Ministry of Agriculture. Retrieved April 2, 2013 (http://www. agriculture.gov.sk.ca).

Smith, M. S. and B. Foran. 1992. “An Approach to Assessing the Economic Risk of Different Drought Management Tactics on a South Australian Pastoral Sheep Station.” Agricultural Systems 39(1):83-105.

Statistics Canada. 2012. “2011 Census of Agriculture.” Customized information on mixed crop and beef farm at province and census division made available by Kathy Larson, Beef Economist at Western Beef Development Center, Canada.

- 2014a. Farm Product Prices, Crops and Livestock. CANSIM table 002-0043. Retrieved December 16, 2014 (http://www5.statcan.gc.ca/cansim/a26?lang=eng\&retrLang =eng\&id $=0020043 \& p a S e r=\& p a t t e r n=\& s t B y V a l=1 \& p 1=1$ \&p2=-1\&tabMode=dataTable\&csid).

- 2014b. Farm Input Price Index. CANSIM tables 328-0006, 328-0007, 328-0004, and 328-0005. Retrieved December 16, 2014 (http://www23.statcan.gc.ca/imdb/ p2SV.pl? Function=getSurvey\&SDDS=2305).

Thornton, P., M. Herrero, A. Freeman, O. Mwai, E. Rege, P. Jones, and J. McDermott. 2008. "Vulnerability, Climate Change and Livestock-Research Opportunities and 
Challenges for Poverty Alleviation.” International Livestock Research Institute (ILRI), Kenya. Retrieved (http://ejournal.icrisat.org/SpecialProject/sp7.pdf).

Thorpe, J. 2007. "Saskatchewan Rangeland Ecosystems. Publication 1: Ecoregions and Ecosites.” Saskatchewan Prairie Conservation Action Plan. Saskatchewan Research Council Pub. No. 11881-1E07.

- 2011. "Vulnerability of Prairie Grasslands to Climate Change.” Saskatchewan Research Council. A report prepared for Prairies Adaptation Research Collaborative (PARC). Retrieved (http://www.parc.ca/rac/fileManagem ent/upload/12855-2E11\%20Vulnerability\%20of\%20Grassl ands\%20to\%20climate\%20change.pdf).

Visagie, S. E., and A. H. Ghebretsadik. 2005. "Modelling Risk in Farm Planning.” Agrekon 44(4):561-585.

Zhang, X., L. A. Vincent, W. D. Hogg, and A. Niisoo. 2000. “Temperature and Precipitation Trends in Canada During the 20th Century.” Atmospheric-Ocean 38(3):395-429.

\section{Bios}

Santosh Poudel, Ph.D., former graduate student, Department of Agricultural and Resource Economics, University of Saskatchewan, currently employed as farm income analyst in the policy branch of the Saskatchewan Ministry of Agriculture, Regina, Saskatchewan, Canada; research fields: climate change, beef cattle production, mitigation of greenhouse gas emissions, and prairie agriculture.

Surendra N. Kulshreshtha, Ph.D., professor, Department of Agricultural and Resource Economics, University of Saskatchewan, Saskatoon, Canada; research fields: climate change, greenhouse gas mitigation, adaptation, irrigation adoption, economic impact analysis. 